DOI 10.18551/rjoas.2020-01.06

\title{
SOCIO-ECONOMIC ASSESSMENT OF COASTAL COMMUNITIES IN EAST FLORES MARINE RESERVES OF EAST NUSA TENGGARA PROVINCE, INDONESIA
}

\author{
Paulus C.A.* \\ Department of Aquatic Resource Management, University of Nusa Cendana, Indonesia
}

\author{
Azmanajaya E. \\ Balikpapan State Polytechnic, Indonesia \\ *E-mail: chatepaulus@undana.ac.id \\ ORCID: 0000-0001-8507-3599
}

\begin{abstract}
Marine reserves are marine protected areas with specific characteristic for the purpose of protection of fish species diversity and ecosystem. The purpose of this research to identify economic activities that can produce benefits as optimal as possible for the coastal community of East Flores marine reserves also has the least negative impact on the environment in the vicinity. The results showed that there are 8 important areas, 4 important habitats and 5 important species that are within the East Flores marine reserves. In this area there is no prohibition on fishing known as 'no-fishing area'. Formal rules regarding marine resource management are not made at the village or hamlet level and there are no formal rules applicable. The community has never caused conflicts between users and officers regarding the use and management of marine resources. Monitoring and law enforcement are only carried out by the community when fishing and there is no monitoring and law enforcement by the government through the relevant agencies. According to the communities, the social impact of the management is a prosperous community and income will increase. The biggest economic beneficiaries are fishermen from outside the sample village with larger fleets and fishing gear such as lampara or motorboats with purse seine, longline tuna, double fishing gears such as trawlers and fishing rods in one fishing fleet.
\end{abstract}

\section{KEY WORDS}

Socio-economic assessment, coastal communities, East Flores, marine reserves.

East Flores marine reserves is one of the few protected areas in East Nusa Tenggara. East Flores regency is an archipelago consisting of 17 islands with a land area of $1.812,85$ $\mathrm{km}^{2}$ and sea area of 2.064,65 $\mathrm{km}^{2}$ (BPS, 2018). East Flores located between 08${ }^{\circ} 40^{\prime \prime} \mathrm{E}$ and $122^{\circ} 20^{\prime \prime} \mathrm{W}$ and administratively consists of 121 coastal villages (Figure 1).

In assessing the effectiveness of management, it is necessary to collect social and ecological data from time to time in the areas within the management area as a reference for the success of the management and as a recommendation for managers. Bessie, 2013 stated that the assessment of the fish resource domain in East Flores regency showed a low score with a tendency to overfishing. Some of the factors causing the low fishery production are environmental damage due to human activities such as the disposal of waste and rubbish into the sea, overfishing, reclamation, and destruction of coral reefs that have affected the condition of the sea. Ocean damage that occurs as a result of human activities in meeting the needs of marine resources as an effort to meet market demand.

Other factors that also affect the low fishery production are the suboptimal use of marine potential and vulnerability as well as sea use conflicts. Vulnerability factors arise from the nature of their work. Coastal communities, most of them work as fishermen, are known to be vulnerable to natural hazards, isolation and climate variability often hinders their ability to earn enough to support their livelihoods (Paulus and Fauzi, 2017). Vulnerability at sea and coast has an impact on the uncertainty of the time and location of potential fisheries and fishing activities become more difficult in planning fishing time and location. 
This suboptimal utilization of Indonesia's marine potential is also caused by low infrastructure support, capital, low human resources, lack of knowledge and technology especially related to fisheries and marine affairs, and a lack of institutions for the marine sector. The solution to this problem is management. Paulus and Sobang (2017) stated that although the community had access to these resources, it did not have a significant effect on the welfare of the community, for this reason, efforts to optimize natural resources management are needed. In the planning of sea space, it is better to pay attention to local wisdom and culture in the area, and involve the community in its planning so that there is no overlap between the community and the plans determined. In addition, if local communities are involved in the planning process, the community will feel obliged to protect the sea. According to Pellokila and Paulus, 2013 each activity of utilizing natural resources (economic activities) does not stand alone, but rather interacts with each other and impacts each other. Paulus and Sobang, 2015 stated that one of the challenges in developing fisheries activities is that the potential of marine fisheries has not been mapped accurately and the lack of control over the implementation of the spatial plan which causes land use that is not in accordance with its designation.

The purpose of conducting socio-economic studies in the East Flores marine reserves is to obtain repetitive data and the latest information on the social, economic and cultural conditions of the community in the East Flores marine reserves and to provide recommendations for adaptive management to the government. In addition, the results of this study can be used to provide information in assessing the impact of the establishment of the East Flores marine reserves on the socio-economic conditions of the community. This study will examine conservation efforts undertaken for good impact on the community.

\section{METHODS OF RESEARCH}

The socioeconomic study in the natural reserve of East Flores waters took place in October 2017 to February 2018. Location observations will be carried out in 13 villages within the East Flores marine reserves. the location of the socio-economic study sample village around East Flores marine reserves is presented in Figure 1 and marked by red polygons.

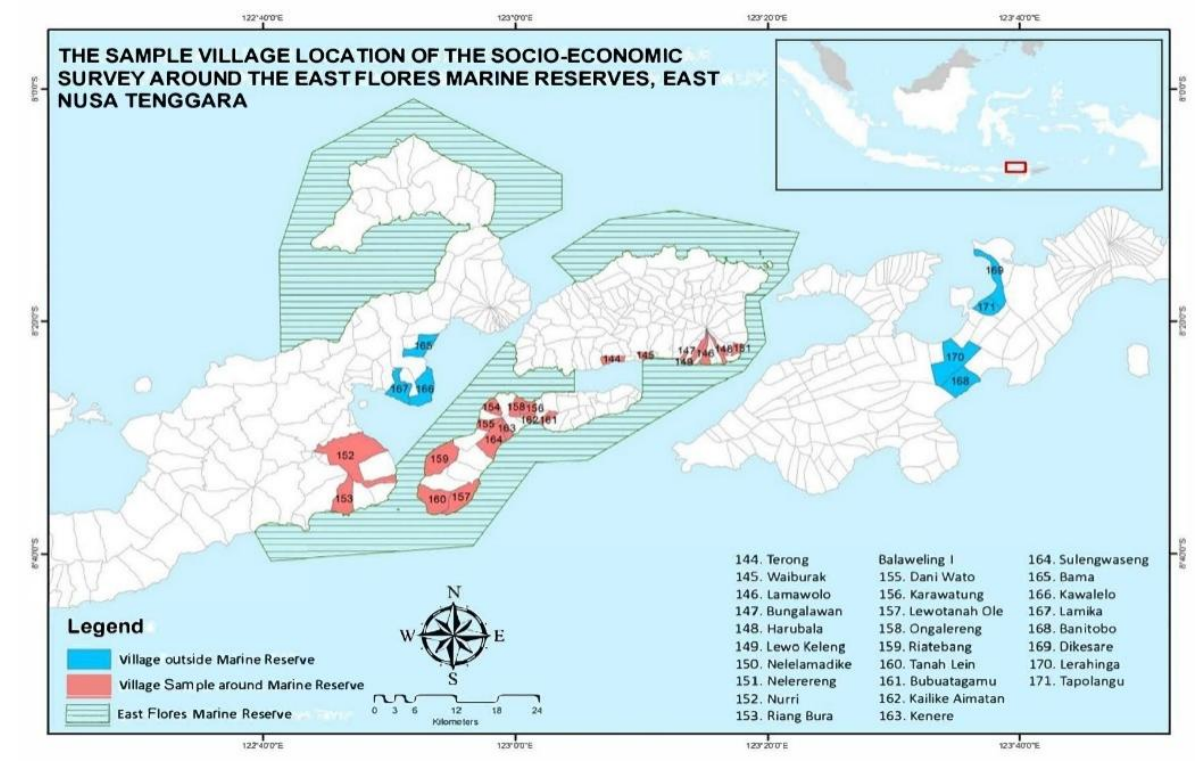

Figure 1 - Location of Data Collection in the East Flores Marine Reserves Area

Some parameters observed include four components, namely: (1) decision making related to marine resource management, (2) regulations related to sea resources, (3) monitoring and law enforcement, and (4) conflict resolution. Methods of data collection through focus group discussion and key informant interviews in the East Flores marine reserves. 


\section{RESULTS AND DISCUSSION}

The important region in this study includes eight waters which are: Podor cape, Kowo bay, Bledewutun cape, Lamawohong cape, Wailonga cape, Lereng cape, Flores strait and the Savu Sea (WWF, 2011). Table 1 presents fishing locations, types of boats and names of research areas. In fact, the internal and external boundaries of the waters do not exist in the East Flores marine reserves area. Fishermen are still free to go to sea and do not have restrictions that are obeyed and apply to all fishermen in East Flores marine reserves. For this reason, the internal and external boundaries of the waters are based on the estimated farthest distance of fishermen going to sea as the maximum limits of internal waters. The internal waters limit is the limit used for fishing communities carrying out fishing activities. The internal limits of these waters can be used freely by the people of Solor Island and Flores Island and the people in the surrounding islands. On the external boundaries of the waters, measured from outside the internal boundaries towards the Savu Sea and the Flores sea. At this limit, the community can still carry out fishing activities a little distance from the internal boundaries, but with the type of boat that is still traditional community causes the community rarely do fishing activities on these external boundaries. Important regions in the East Flores marine reserves are the most frequently area visited by fishing communities to conduct fishing activities. These important areas are often visited by people around the East Flores Regency, such as fishermen from Alor Island, Lembata Island, and other islands from the western part of Flores. In detail, important areas of fishing locations and types of boats used by the community to travel to these important areas are presented in Table 1 below.

Table 1 - Fishery Activities in East Flores Marine Reserve based on Fishing Location, Boat Type

\begin{tabular}{llll}
\hline No & Village & Fishing Location & Boat Type \\
\hline 1 & Dani Wato & Flores strait & craft \\
\hline 2 & Kenere & Savu sea & motorboat \\
\hline 3 & Balaweling I & Flores strait & motorboat 3GT \\
\hline 4 & Ongalereng & Podor cape, Solor strait & motorboat <3GT \\
\hline 5 & Sulengwaseng & Savu sea & craft \\
\hline 6 & Ritaebang & Flores strait & craft \\
\hline 7 & Karawatung & Podor cape, Solor strait & motorboat \\
\hline 8 & Kalike Aimatan & Kowo bay, Savu sea & craft \\
\hline 9 & Bubu Atagamu & craft \\
\hline 10 & Tanah Lein & Kowo bay, Savu sea & craft \\
\hline 11 & Lewo Tanah Ole & Bledewutun cape, Savu sea & craft \\
\hline 12 & Nurri & Lamawohong cape, Savu sea & motorboat <3GT \\
\hline 13 & Riang Bura & Wailonga cape, Flores strait & craft \\
\hline
\end{tabular}

Most of the fishermen (61.5\%) in East Flores marine reserves still use a simple type of boat, namely craft and the remaining $38.5 \%$ of fishermen use boats with movers or motorboats. The condition of this fishing fleet causes fishermen to only carry out fishing activities within the area with internal restrictions only.

There are 4 important habitats within the East Flores marine reserves namely mangroves, seagrass beds, seaweeds and coral reefs, while 5 important species found are manta rays, dolphins, whales, sharks and turtles. The existence of top-level predatory animals such as sharks and whales that are always present in every waters shows that the balance of the ecosystem, especially in the food chain is still maintained.

Griffin et al. (2008) stated that sharks as top predators, help to manage healthy ocean ecosystems. And as the number of large sharks' declines, the oceans will suffer unpredictable and devastating consequences. Sharks help maintain the health of ocean ecosystems, including seagrass beds and coral reefs. Healthy oceans undoubtedly depend on sharks.

Whales can also transport nutrients to surface waters by releasing fecal plumes and urine in their feeding areas, as they respire, digest, metabolize, or rest at or near the ocean surface (Roman and McCarthy, 2010). Roman et al. (2014) also stated that "whale pump" likely plays a role in enhancing productivity in biological hotspots (i.e. regions of high primary productivity that are associated with rich and diverse upper trophic levels). Turtles also play 
an important role in ocean ecosystems by maintaining healthy seagrass beds and coral reefs, providing key habitat for other marine life, helping to balance marine food webs and facilitating nutrient cycling from water to land (Wilson et al., 2010).

Table 2 - Types of Habitat and Species in East Flores Marine Reserves

\begin{tabular}{llll}
\hline No & Village & Types of Habitat & Types of Species \\
\hline 1 & Dani Wato & $\begin{array}{l}\text { coral reef, mangrove, seagrass, } \\
\text { seaweed }\end{array}$ & $\begin{array}{l}\text { manta rays, dolphins, whales, whale sharks, green turtles and } \\
\text { hawksbill turtles }\end{array}$ \\
\hline 2 & Kenere & coral reef, mangrove, seaweed & whale sharks, whales, green turtles, manta rays, dolphins \\
\hline 3 & Balaweling I & $\begin{array}{l}\text { coral reef, mangrove, seagrass, } \\
\text { seaweed }\end{array}$ & manta rays, whales, turtles, white sharks, dolphins \\
\hline 4 & Ongalereng & coral reef, mangrove & whales, sharks, manta rays, green turtles, dolphins \\
\hline 5 & Sulengwaseng & coral reef, mangrove, seagrass & whales, turtles, sharks, manta rays, dolphins \\
\hline 6 & Ritaebang & coral reef, mangrove, seaweed & green turtles, dolphins, sharks, manta rays, whales \\
\hline 7 & Karawatung & coral reef & dolphins, whales, sharks, hawksbill turtles, manta rays \\
\hline 9 & Kalike Aimatan & coral reef, mangrove & whales, dolphins, turtles, manta rays, sharks \\
\hline 9 & Bubu Atagamu & coral reef & $\begin{array}{l}\text { whales, dolphins, manta rays, sharks, hawksbill and green } \\
\text { turtles }\end{array}$ \\
\hline 10 & Tanah Lein & coral reef & green turtles, sharks, whales, dolphins, manta rays \\
\hline 11 & Lewo Tanah Ole & coral reef & whales, sharks, dolphins, manta rays, turtles \\
\hline 12 & Nurri & coral reef, mangrove, seagrass & whales, dolphins, turtles, sharks, manta rays \\
\hline 13 & Riang Bura & coral reef & whales, sharks, dolphins, manta rays, turtles \\
\hline
\end{tabular}

In general, fishermen in East Flores marine reserves still use simple fishing gear such as fishing rods and trawlers as shown in Figure 2, and the habit of capturing sea products at low tide "Meting" can be seen in Figure 3. While fishermen catch on Solor Island and Flores Island are presented in Table 4.

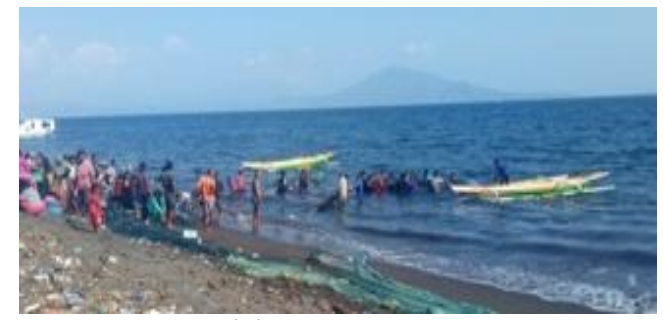

(a) beach trawl

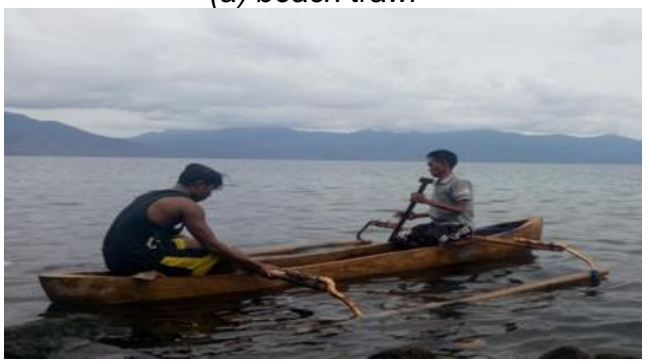

(c) hand fishing rod

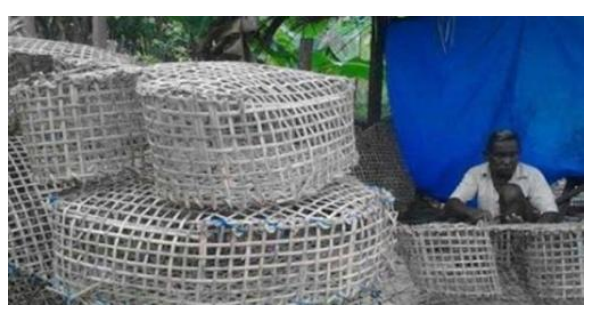

(b) traps (local name: bubu)

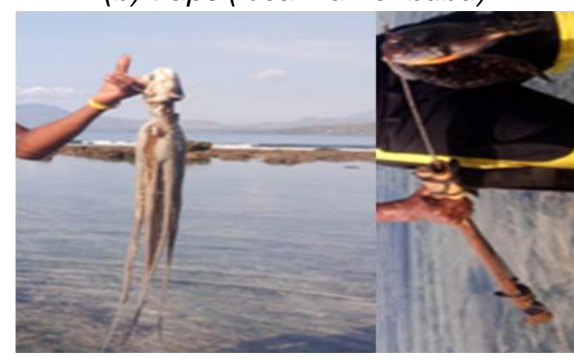

(d) arrow fishing

Figure 2 - Various Fishing Gear Used by fishermen in East Flores Marine Reserves

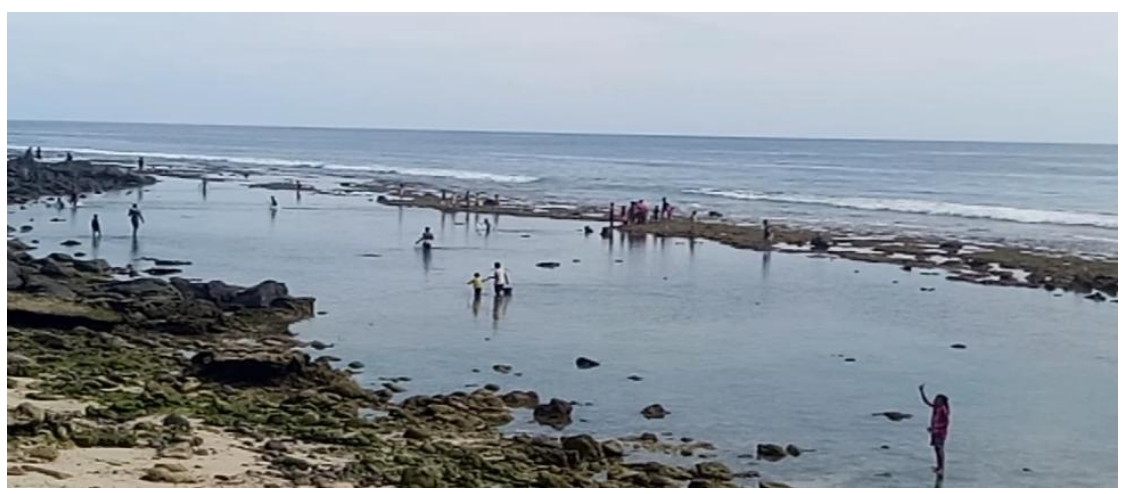

Figure 3 - "Meting" Activity (taking sea produce during low tide) 
Based on the fishing gear used by fishermen and the fishing activities carried out as in Figure 3 , the catch is obtained as shown in Table 4.

Table 4 - Fishermen's Catch Results based on Fishing Gear and Fishing Activity

\begin{tabular}{|c|c|c|}
\hline No & $\begin{array}{l}\text { Fishing Gear and } \\
\text { Fishing Activity }\end{array}$ & Type of sea catch \\
\hline 1 & Beach Trawl & $\begin{array}{l}\text { The types of pelagic fish and demersal fish includes: Anchovies (Stolephorus spp.), types of } \\
\text { Shrimp, Parupeneus spp., Shark, Setipinna spp., Stingray, Saurida spp., etc. }\end{array}$ \\
\hline 2 & $\begin{array}{l}\text { Bottom Traps or } \\
\text { "Bubu Dasar" }\end{array}$ & $\begin{array}{l}\text { Shrimps, Giant trevally (Caranx spp), Baronang (Siganus spp), Grouper (Epinephelus spp), } \\
\text { Snapper (Lutjanus spp), Yellowtail fish (Caesio spp), and Crabs. }\end{array}$ \\
\hline 3 & Hand Fishing Rod & $\begin{array}{l}\text { Stingray, Rabbitfish (Siganus spp), Grouper (Epinephelus spp), Snapper (Lutjanus spp), Yellowtail } \\
\text { fish (Caesio spp), Threadfin Bream (Nemipteridae), Shark (Sphyrna blochii) and others. }\end{array}$ \\
\hline 4 & Arrow Fishing & $\begin{array}{l}\text { Octopus, Squid, Rabbitfish (Siganus spp), various kinds of grouper fish, Snapper (Lutjanus spp), } \\
\text { Crabs, and various other types of reef fish. }\end{array}$ \\
\hline 5 & "Meting" Activity & $\begin{array}{l}\text { Octopus, squid, Rabbitfish (Siganus spp), various kinds of grouper fish, various kinds of crab, } \\
\text { various kinds of reef fish, various kinds of sea vegetables (algae), and various kinds of snails or } \\
\text { shellfish. }\end{array}$ \\
\hline
\end{tabular}

Based on the results of group discussions with the community in the study villages, no fishing prohibition areas were found, this condition made fishermen free to catch around the waters of the Flores strait, the Solor strait and the Savu sea. The size of the existing fishing area will be adjusted to the type of fleet or boat used by fishermen.

The fish landing location in East Flores is in the "Larantuka Inpres" Market which is the main market in East Flores regency. However, the activity of landing fish to the Inpres Larantuka market from a number of villages around East Flores marine reserves is very minimal due to fishing activities at sea is a side job and usually this fishing activity is only to get sea products intended for consumption in their respective households or as barter goods or sold to neighboring houses. Percentage of seafood consumed and used as barter or sold by East Flores fishermen can be seen in Figure 4.

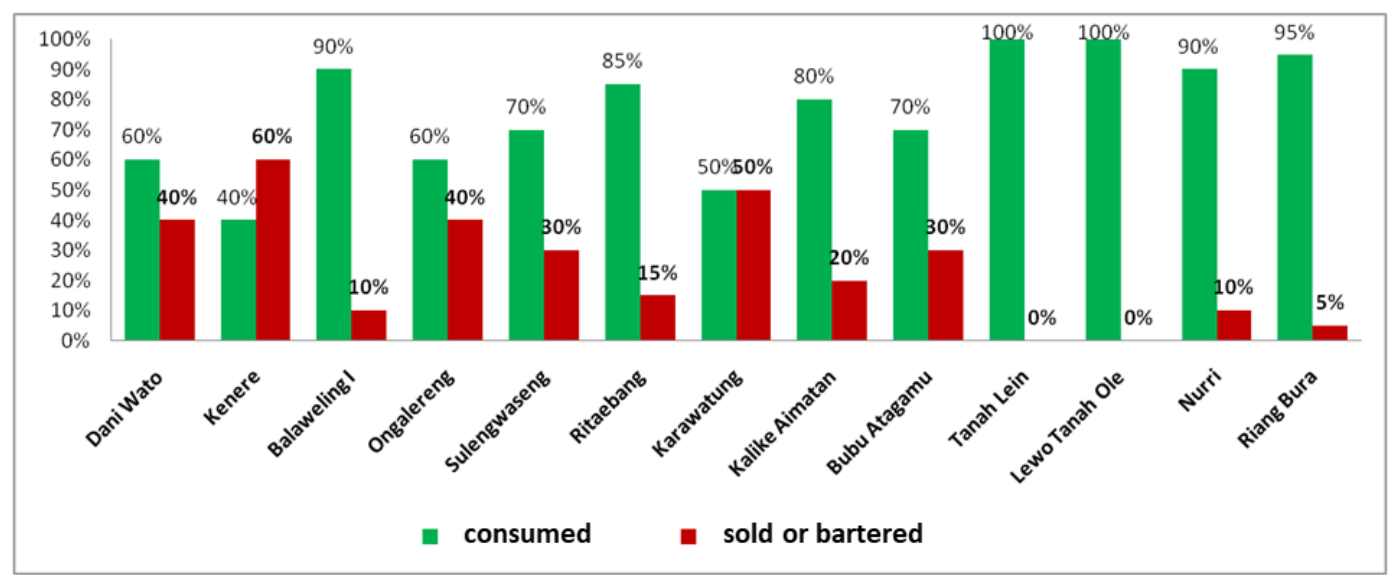

Figure 4 - Sea Products Percentage of Consumed and Sold or Bartered by Communities in the Sample Village area of East Flores Marine Reserves

There are 71 user groups in East Flores marine reserves (Table 5). The user groups in East Flores marine reserves are divided based on the type of catch produced, such as groups of fishermen from types of reef fish, basic fish, small and large pelagic, sea cucumbers, lobsters, pearl oysters, squid, shrimp, and octopus. While users outside East Flores marine reserves come from the areas of Lembata, Adonara, Bima, Maumere, Makassar, Lamahala, Lamakera and Ende. Until now, no organizations or institutions have been formed in the village and there are no NGOs managing marine resources around East Flores marine reserves. Monitoring activities are not carried out by the government, village communities, domestic or foreign NGOs and there are no regulations on other users from outside before conducting fishing operations in the sample village area. Also, users in 13 sample villages did not supervise the level of community welfare. 
Table 5 - User Groups and Types of Activities Undertaken in East Flores Marine Reserves

\begin{tabular}{|c|c|c|c|}
\hline No & Village & User Groups & Types of Activities \\
\hline 1 & Dani Wato & $\begin{array}{l}\text { Nets fishermen from Dani Wato } \\
\text { Trawlers from Dani Wato } \\
\text { Seine fishermen from East Adonara } \\
\text { Seine fishermen from East Solor }\end{array}$ & $\begin{array}{l}\text { Big and small pelagic fishing, reef fish } \\
\text { and demersal fishing, octopus fishing and } \\
\text { crustaceans. }\end{array}$ \\
\hline 2 & Kenere & $\begin{array}{l}\text { Rods fishermen from Kenere } \\
\text { Trawlers from Kenere } \\
\text { Spear fishermen from Bima } \\
\text { Purse seine fishermen from Larantuka } \\
\text { Purse seine fishermen from Adonara } \\
\text { Purse seine fishermen from Maumere }\end{array}$ & $\begin{array}{l}\text { Big and small pelagic fishing, reef fish } \\
\text { and demersal fishing, also fishing for } \\
\text { lobster, octopus, pearl oysters and } \\
\text { crustaceans. }\end{array}$ \\
\hline 3 & Balaweling I & $\begin{array}{l}\text { Rods fishermen from Solor } \\
\text { Trawlers from Solor } \\
\text { Trawlers from Lohayong } \\
\text { Nets fishermen from Bima } \\
\text { Nets fishermen from Lamahayong }\end{array}$ & $\begin{array}{l}\text { Reef fish and demersal fishing, big and } \\
\text { small pelagic fishing, also fishing for } \\
\text { lobster, octopus, pearl oyster and } \\
\text { crustaceans. }\end{array}$ \\
\hline 4 & Ongalereng & $\begin{array}{l}\text { Rods fishermen from Solor } \\
\text { Trawlers from Solor } \\
\text { Spear fishermen from Bima } \\
\text { Trawlers from Lohayong } \\
\text { Trawlers from Terong }\end{array}$ & $\begin{array}{l}\text { Reef fish and demersal fishing, big and } \\
\text { small pelagic fishing, also fishing for } \\
\text { squid, lobster and crustaceans. }\end{array}$ \\
\hline 5 & Sulengwaseng & $\begin{array}{l}\text { Rods fishermen from Solor } \\
\text { Rods fishermen from Ende } \\
\text { Trawlers from Lamakera } \\
\text { Trawlers from Lembata } \\
\text { Trawlers from Lamahala }\end{array}$ & $\begin{array}{l}\text { Reef fish and demersal fishing, big and } \\
\text { small pelagic fishing, also fishing for } \\
\text { squid, lobster and pearl oyster. }\end{array}$ \\
\hline 6 & Ritaebang & $\begin{array}{l}\text { Nets fishermen from Solor } \\
\text { Purse seine fishermen from Bajo } \\
\text { Purse seine fishermen from Adonara } \\
\text { Rods fishermen from Maumere } \\
\text { Rods fishermen from Larantuka } \\
\text { Lobster collector fishermen from Alor } \\
\text { Longline fishermen from Makassar }\end{array}$ & $\begin{array}{l}\text { Reef fish and demersal fishing, big and } \\
\text { small pelagic fishing, also fishing for } \\
\text { squid, octopus, lobster and pearl oyster. }\end{array}$ \\
\hline 7 & Karawatung & $\begin{array}{l}\text { Trawlers from Solor } \\
\text { Rods fishermen from Solor } \\
\text { Longline fishermen from Karawatung } \\
\text { Purse seine fishermen from Lembata } \\
\text { Trawlers from Lohayong }\end{array}$ & $\begin{array}{l}\text { Reef fish and demersal fishing, big and } \\
\text { small pelagic fishing. }\end{array}$ \\
\hline 8 & Kalike Aimatan & $\begin{array}{l}\text { Nets fishermen from Solor } \\
\text { Trawlers from East Solor } \\
\text { Rods fishermen from Solor } \\
\text { Trawlers from Lembata } \\
\text { Octopus spear fishermen from Ende }\end{array}$ & $\begin{array}{l}\text { Reef fish and demersal fishing, large and } \\
\text { small pelagic fishing, also fishing for } \\
\text { squid, octopus and lobster fishing. }\end{array}$ \\
\hline 9 & Bubu Atagamu & $\begin{array}{l}\text { Rods fishermen from Bubu Atagamu } \\
\text { Traps fishermen from Bubu Atagamu } \\
\text { Trawlers from Bubu Atagamu } \\
\text { Spear fishermen from Bubu Atagamu } \\
\text { Trawlers from Lewubelarang } \\
\text { Trawlers from Lamahala }\end{array}$ & $\begin{array}{l}\text { Reef fish and demersal fishing, large and } \\
\text { small pelagic fishing, squid fishing, and } \\
\text { octopus fishing. }\end{array}$ \\
\hline 10 & Tanah Lein & $\begin{array}{l}\text { Trawlers from Tanah Lein } \\
\text { Rods fishermen from Tanah Lein } \\
\text { Traps fishermen from Tanah Lein } \\
\text { Purse seine fishermen from East Solor } \\
\text { Purse seine fishermen from Adonara } \\
\text { Trawlers from Ende } \\
\text { Lobster spear fishermen from Bima }\end{array}$ & $\begin{array}{l}\text { Reef fish and demersal fishing, large and } \\
\text { small pelagic fishing, also fishing for } \\
\text { lobster, octopus and crustaceans. }\end{array}$ \\
\hline 11 & Lewo Tanah Ole & $\begin{array}{l}\text { Trawlers from Lewo Tanah Ole } \\
\text { Rods fishermen from Lewo Tanah Ole } \\
\text { Purse seine fishermen from East Solor } \\
\text { Purse seine fishermen from Adonara }\end{array}$ & $\begin{array}{l}\text { Big and small pelagic fishing, reef fish } \\
\text { and demersal fishing. }\end{array}$ \\
\hline 12 & Nurri & $\begin{array}{l}\text { Purse seine fishermen from East Solor } \\
\text { Purse seine fishermen from Lamahala } \\
\text { Purse seine fishermen from Adonara } \\
\text { Purse seine fishermen from Ende } \\
\text { Longline Tuna fishermen from Bima } \\
\text { Longline Tuna fishermen from Buton } \\
\text { Octopus Rods fishermen from Sikka }\end{array}$ & $\begin{array}{l}\text { Reef fish and demersal fishing, large and } \\
\text { small pelagic fishing, also fishing for } \\
\text { squid, octopus, lobster and pearl oyster. }\end{array}$ \\
\hline 13 & Riang Bura & $\begin{array}{l}\text { Rods fishermen from Waibula } \\
\text { Rods fishermen from Riang Bura } \\
\text { Traps fishermen from Riang Bura } \\
\text { Trawlers from Solor } \\
\text { Trawlers from Riang Bura }\end{array}$ & $\begin{array}{l}\text { Reef fish and demersal fishing, big and } \\
\text { small pelagic fishing, also squid fishing. }\end{array}$ \\
\hline
\end{tabular}


Based on the results of group discussions with the communities of the 13 sample villages there were no stakeholders participating in the establishment of regulations that took place in the village, no one played a role in determining village boundaries, no one designed an organization in the sample villages, there was no regulation making regulates marine resource management, and no one is monitoring the condition of marine resources in the sample villages. Several studies have addressed the concerns for a successful and effective community-based marine protected area (MPA) management practices in the country and these researches identified local residents' involvement as one of the important factors (Pollnac et al., 2001; Pomeroy and Carlos, 1997). Involvement of the community in the management of MPAs is essential because of their traditional knowledge and are direct users of the resources (Fernandez and Subade, 2015). Ballad et al., 2016 stated that awareness on the importance of resources stimulates the participation of the community and a continuous environmental education that would elicit consciousness should be undertaken.

Based on the results of studies and discussions, formal rules are not made at the village or hamlet level and there are no formal regulations for the management of marine resources that apply. From observations and discussions during the field, central and regional government regulations have never been socialized to the community in 13 sample villages, and until now respondents also did not know the formal rules from the central and local governments.

As for the rules that were posted at the entrance of the Bubu Atagamu village office regarding the prohibition on catching manta rays from the Ministry of Maritime Affairs and Fisheries, Wildlife Conservation Society and the government of East Nusa Tenggara province (Figure 6a). However, this rule was only posted and never socialized to the whole village community so that most of the respondents' answers knew the prohibition on manta rays but did not know for sure what form of rules and sanctions were given.

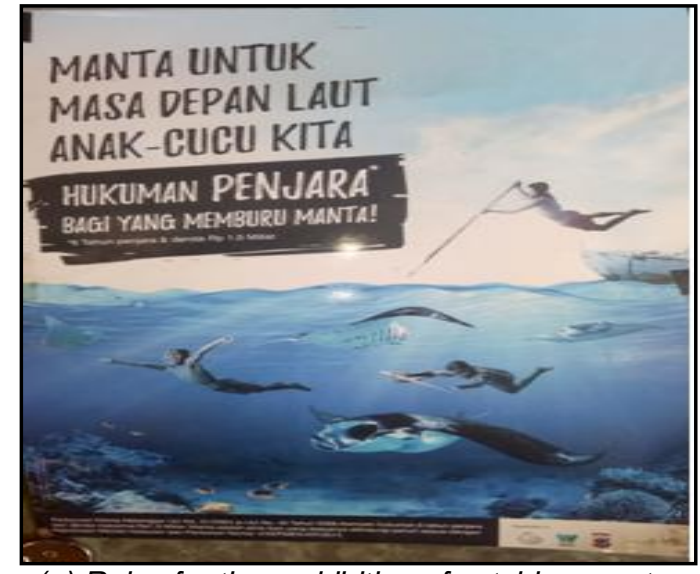

(a) Rules for the prohibition of catching mantas

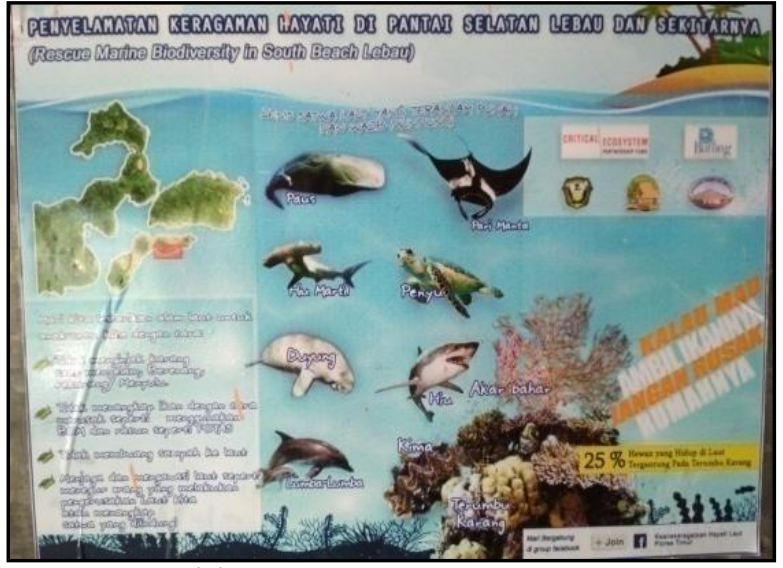

(b) Biodiversity Rescue Rules

Figure 6 - Formal Management Rules in Bubu Atagamu village

The informal rules regarding the prohibition of catching sea turtles, manta rays, dolphins obtained by word of mouth, have never been conveyed directly from the local government or related agencies to the village community. This can be seen from the response of the community when asked about the source of information on informal rules about the prohibition of protected animals. Informal rules on animal protection are found in Bubu Atagamu village, which is saving biodiversity on the south beach of Lebau and its surroundings. This regulation was made by a local NGO called the "Tanah lle Boleng" foundation in collaboration with the Critical Ecosystem Partnership Fund, the Indonesian Bird Foundation, YPPS Eco Flores Foundation, and the East Flores regional government. This rule is posted at the entrance of the village office building as shown in Figure 6b.

Not all villages in East Flores marine reserves have information about the history of marine resource management. In general, there is a history of traditional rituals or 
ceremonies when they first have a new fleet and fishing gear and will go to sea for the first time. These rituals or ceremonies are led by traditional elders or so-called "OPU-EPU" (traditional descendants who are appointed by the tribe as servants). The materials commonly used in this traditional ceremony are the blood of local chickens and coconut leaves, and even some other villages use coconut water. This ritual is held with the aim of avoiding distress and getting a fortune in the form of marine products. Karawatung village calls this traditional ceremony by the name of "SU'U WENr". The first sea products from fishing must be given to sisters of merchants who have fleets or fishing gears.

Another form of historical information found is the history of how to catch fish. "Pematang Laut" also known as "Batu Susun" or fish trap is one of the traditional ways to catch fish. The arrangement of stones formed towards the sea and conical inward like a fish trap model. The location of "Pematang Laut" is scattered in several coastal waters of Ongalereng village. At present, the "Pematang Laut" has been abandoned, fishermen are no longer using sea bunds and have switched to string fishing. In Sulengwaseng village, the same history is found but is known locally as "ATU" which functions like a fish trap, but now that " $A T U$ " has been abandoned, Sulengwaseng fishermen now use fishing rods from the strings just like Ongalereng fishermen.

There is no involvement of community groups using marine resources either in the management of marine resources nor in monitoring the condition of the sea or the activeness in participation in making regulations at the local government level, especially management of marine resources. This is supported by the statement of the respondents that the waters in the 13 sample villages do not yet have any marine resource management rules. However, there is a willingness from the user group to participate in making regulations as well as fishing restrictions because up to now fishermen from outside the sample villages are catching in the waters of their villages with large fleets and large fishing gears. This is the reason the local community wants to have regulations or management of marine resources in the village and its surroundings, besides the waters can be maintained and local fishermen can catch in their own waters.

The decision-making process is carried out jointly between the community, traditional elders and village officials in the village hall or village office. Decision-making related to the utilization and management of marine resources has never been done, this is due to the absence of local values and beliefs related to decision making and management of marine resources. Thus, there is no participation in making regulations governing management in East Flores marine reserves.

There was once a conflict with fishermen from outside the village for fish bombing and cyanide use, and even then, it could not be said to be a conflict because it was only an argument between fishermen and ended with eviction from the fishing area, not to complaints to the authorities. However, in the past 15 years, there were no conflicts between fishermen in the East Flores marine reserves. The awareness that the sea is joint ownership makes the social conditions of the community safe. The community has never caused conflicts between users and officers regarding the use and management of marine resources.

According to the results of discussions with key informants, the community believes that the social impact of management is prosperous society and increased income. This is based on the understanding of the community that if capture fisheries become the main sector in this case the main livelihood will be very helpful to increase income in addition to being a farmer. This is in line with Paulus et al., 2019 which states that alternative business needs to be developed as a form of adaptation of fishermen households in maintaining income which is caused by a decrease in income from the main livelihoods as fishermen due to seasonal changes. Thus, the standard of living of the people will increase. Another social impact according to the community is that with good management and in accordance with applicable regulations, conflicts of interest between user groups can be guaranteed to be absent, especially if the supervisory function of the authorities runs effectively.

The ecological impact of management according to the community is that the sea is protected, sustainable and marine products such as fish have increased. Community understanding of the preservation of the sea is maintained very high even though 
socialization from related parties is lacking, but from ancient times according to history from the ancestors have taught to treat the sea as part of life so that it should not be carelessly acting at sea and must be maintained good behavior if not then distress even the death of a loved one.

The biggest beneficiaries are fishermen from outside the sample villages with larger fleets and fishing gears such as lampara with purse seines, longline tuna, motorboats with double fishing gears like trawlers and fishing rods in a fishing fleet. When compared to the contribution of marine resources to community income, the value of the contribution is in the range of $1 \%$ to $25 \%$ meaning that the results of capture or marine resources contribute $1 \%$ to $25 \%$ of community income in East Flores marine reserves. This is because most people earn a living as farmers and as fishermen only the main side job and more for consumption in their own households, some villages with a contribution of $1 \%$ due to the demographic conditions of villages far from the coast. The largest contribution of marine products to household income of $20 \%$ to $25 \%$ is in the Kenere village and Ongalereng village; contribution ranges from $10 \%$ to $15 \%$ are in seven villages; while contributions under $5 \%$ are in the four villages.

In most areas of East Flores marine reserves, so far there are no local community management practices for marine resources. Only three villages namely Karawatung village, Kalike Aimata village, and Bubu Atagamu village have a history from the time of their ancestors and up to now it is still valid and there is no change from that history. Existing history in the form of belief in the procedures for sea and stranded marine animals. The three villages that still exert ancestral trust in marine resource management are Karawatung village, Kalike Aimatan village and Bubu Atagamu village.

Karawatung village has a local belief that it should not catch crocodiles because crocodiles are incarnations of the ancestors of local people. If crocodiles are captured by the community there will be a danger of death of a close relative. In contrast to Kalike Aimatan village has a ritual if there are fish stranded or floating fish in the waters or called Wetang fish (consumption fish), first it must be made a new traditional ritual may be consumed, otherwise death will occur. This "Wetang" traditional ritual involves landowners as a mark of respect for land ownership. Similar to Kalike Aimatan village, the traditional ritual is that if a large fish is stranded like a stingray, dolphin, and whale, a ritual will be conducted led by the landlord in Bubu Atagamu village.

However, for the majority of people in Flores East marine reserves, the community always implements traditional ceremonies if they have a new fishing fleet such as "lampara" or motorboats and crafts along with new fishing gear that need to be made an event by a trusted person or traditional elders with traditional materials such as the local chicken blood and coconut water. This ritual is done in order to avoid distress when at sea and to get fortune such as catches from the sea. Another habit that is often practiced by the community is "Meting" (Figure 3), this habit starts at low tide and the community begins to search for fish, crabs or shrimp that are between the corals or sometimes green algae for household consumption. "Meting" is still carried out by the community until now.

\section{CONCLUSION}

The results showed that there are 8 important areas namely Podor cape, Kowo bay, Bledewutun cape, Lamawohong cape, Wailonga cape, Lereng cape, Flores strait and the Savu Sea. In fact, the internal and external boundaries of the waters do not exist in the East Flores marine reserves area. In that area, 4 important habitats are found namely mangroves, seagrass beds, seaweeds and coral reefs, while 5 important species found are manta rays, dolphins, whales, sharks and turtles. In this area there is no prohibition on fishing known as 'no-fishing area'. Formal rules regarding marine resource management are not made at the village or hamlet level and there are no formal rules applicable. The community has never caused conflicts between users and officers regarding the use and management of marine resources. Monitoring and law enforcement are only carried out by the community when fishing and there is no monitoring and law enforcement by the government through the relevant agencies. According to the communities, the social impact of the management is a 
prosperous community and income will increase. The biggest economic beneficiaries are fishermen from outside the sample village with larger fleets and fishing gear such as lampara or motorboats with purse seine, longline tuna, double fishing gears such as trawlers and fishing rods in one fishing fleet.

\section{ACKNOWLEDGEMENTS}

The authors wish to acknowledge WWF-Indonesia for providing the funding of this research through 2017-2018 grant.

\section{REFERENCES}

1. [BPS] Central Bureau of Statistics. 2018. East Flores in Figures. Central Statistics Agency for East Flores Regency. Larantuka.

2. Ballad, E. L., Yoshinori Morooka, and Teruyuki Shinbo. 2016. Factors Inducing Community Participation in Coastal Resource Management: Case Study of MPAs in Gonzaga, Cagayan, Philippines. Journal of Rural Problems 52(4), 241-246.

3. Bessie, Donny M. 2013. Fisheries Management with an Ecosystem Approach in East Flores Regency. Research Report. Faculty of Fisheries and Marine Science. Universitas Kristen Artha Wacana. Kupang. NTT.

4. Fernandez, C. and Subade, R. (2015) Perceptions toward marine reserves in lloilo coastal communities, Central Philippines. Asian Fisheries Science, 28, 198-212.

5. Griffin, E., Miller, K.L., Freitas, B. and Hirshfield, M. 2008. Predators as Prey: Why Healthy Oceans Need Sharks. OCEANA. 20pp. Washington, DC. USA.

6. Paulus C. A., Pellokila M. R., Sobang Y. U. L., Azmanajaya E., 2019 The alternative livelihood development strategy in order to improve local fishermen revenue in the border region of Indonesia and Timor Leste. AACL Bioflux 12(1):269-279.

7. Paulus, C.A. 2015. Strategy for Sustainable Management of Fisheries and Animal Husbandry as the Leading Business Sector in East Nusa Tenggara. National Seminar Proceeding. Research and Community Service Institutions of Jambi University. Jambi.

8. Paulus, C. (2017). Factors Affecting Sustainability of alternatives livelihood in coastal community of Nembrala East Nusa Tenggara: An Application of MICMAC Method. Jurnal Ekonomi Pembangunan: Kajian Masalah Ekonomi and Pembangunan, 18(2), 34-41.

9. Paulus $C A$. and $Y \cup L$. Sobang. 2017. Alternative livelihood strategy to improve social resilience of fisher households: a case study in Nembrala Village of Rote Ndao Regency]. Journal of Economic and Social of Fisheries and Marine, 5(1):13-21.

10. Pellokila, Marthen R. and Chaterina A. Paulus. 2013. Economic Valuation of Regional Aquatic Conservation Area in Alor Regency. Research Report. Faculty of Marine Science and Fisheries. Nusa Cendana University. Kupang. NTT.

11. Pollnac, R., Crawford, B. and Gorospe, M. (2001) Discovering factors that influence the success of community-based marine protected areas in the Visayas, Philippines. Ocean \& Coastal Management, 44(11-12), 683-710.

12. Pomeroy, R. and Carlos, M. (1997) Community-based coastal resource management in the Philippines: A review and evaluation of programs and projects, 1984-1994. Marine Policy, 21(5), 445-464.

13. Roman $\mathrm{J}$ and McCarthy JJ. 2010. The whale pump: marine mammals enhance primary productivity in a coastal basin. PLoS ONE 5: e13255.

14. Roman Joe, James A Estes, Lyne Morissette, Craig Smith, Daniel Costa, James McCarthy, JB Nation, Stephen Nicol, Andrew Pershing, and Victor Smetacek. 2014. Whales as marine ecosystem engineers. Front Ecol Environ 2014; doi:10.1890/130220.

15. Wilson, E.G., Miller, K.L., Allison, D. and Magliocca, M. 2010. Why Healthy Oceans Need Sea Turtles: The Importance of Sea Turtles to Marine Ecosystems. OCEANA. Protecting the World's Oceans. 20pp. Washington, DC. USA.

16. World Wild Foundation. 2011. Pemantauan Pemanfaatan Sumber daya Kawasan Konservasi Perairan Daerah Kabupaten Alor. WWF-Indonesia, Solor-Alor Project. Alor. 